\title{
Parietal Lipomeningocele
}

\section{-Case Report-}

\author{
Shiro YAmashita, Katsuzo KUnishio, Takashi TAmiYa, Takehiro NAKAmURA, \\ Daisuke OGAWA, Hiroharu H. IGAWA*, Yasuhiro KURODA**, \\ and Seigo NAGAO
}

\begin{abstract}
Departments of Neurological Surgery, *Plastic and Reconstructive Surgery, and ** Anesthesiology and Emergency Medicine, Kagawa University School of Medicine, Kagawa
\end{abstract}

\begin{abstract}
A 2-month-old female infant had had a parietal mass since birth. Neuroimaging revealed a lipoma under the splenium of the corpus callosum that was connected to the subcutaneous lipoma via a bone defect in the cranium bifidum of the parietal region. At the age of 5 months, partial resection of only the extracranial mass was carried out. The histological diagnosis was lipoma. She grew up normally without neurological disorders during follow up for 12 years after the surgery. In the present case, the intracranial lipoma was associated with the cranium bifidum, and dysraphism was possibly involved in the pathogenesis. Resection of only the extracranial subcutaneous tumor can be performed for cosmetic reasons.
\end{abstract}

Key words: intracranial lipoma, cranium bifidum, dysraphism, bone defect, extracranial extension

\section{Introduction}

Intracranial lipoma is a rare disease which accounts for $0.1-0.5 \%$ of all intracranial tumors. ${ }^{4,5)}$ Intracranial lipoma frequently develops in the supratentorial midline region, mostly in the corpus callosum. ${ }^{4,19}$ The etiology is still controversial. ${ }^{19)}$ Intracranial lipoma may be associated with cranium bifidum, which is a form of dysraphism. ${ }^{11,20)}$ Intracranial lipoma associated with an extracranial extension is extremely rare.

Here we describe a rare case of lipoma located under the splenium of the corpus callosum associated with an extracranial extension via a bone defect in the cranium bifidum of the parietal region of the head. This case was followed up for 12 years without manifesting any particular neurological findings.

\section{Case Report}

A 2-month-old female infant, who was born at 40 weeks 3 days' gestation with a birth weight of $2578 \mathrm{~g}$ by normal vaginal delivery, was taken to our

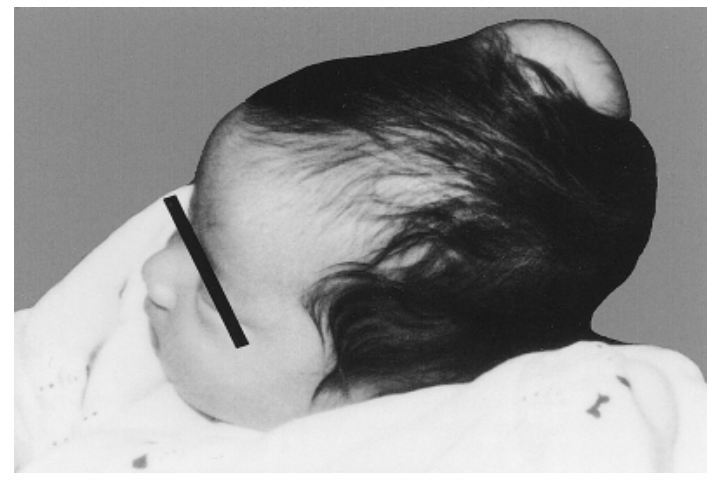

Fig. 1 Photograph of the tumor at the initial presentation. The tumor was located in the parietal region and had a soft and elastic consistency. The surface of the tumor was hairless.

hospital in January 1992 for treatment of a congenital parietal tumor. The tumor measured $4 \mathrm{~cm} \times$ $4 \mathrm{~cm}$, and consisted of soft and elastic tissues, with no hair on its surface (Fig. 1). There was no change in the tumor size when she was weeping. Neuro-

Received May 18, 2004; Accepted September 1, 2004

Author's present address: S. Yamashita, M.D., Department of Neurosurgery, University of Michigan, Ann Arbor, Michigan, U.S.A. 

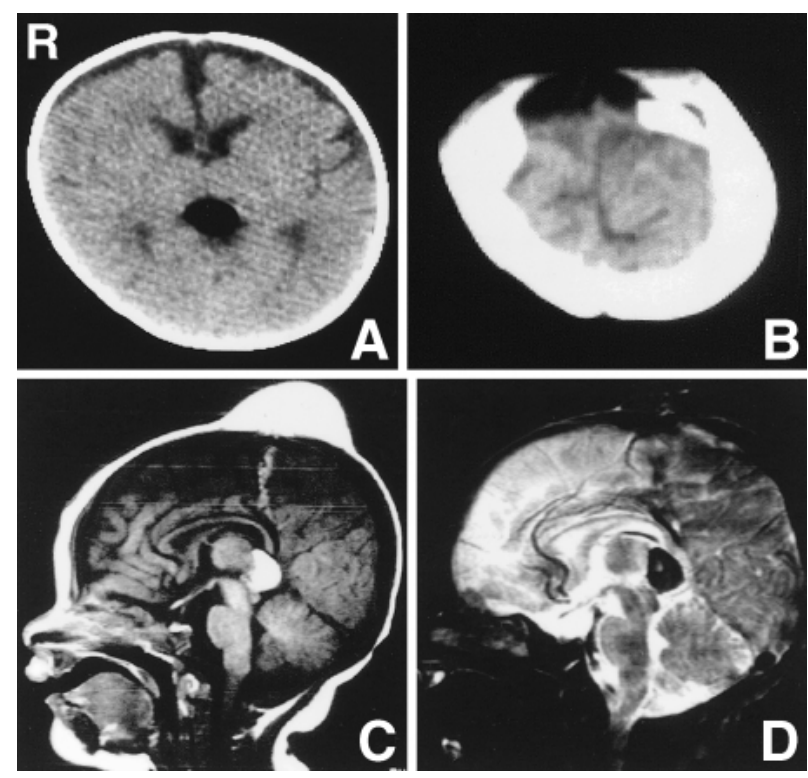

Fig. 2 Preoperative axial computed tomography scans $(A, B)$ at the age of 4 months showing a low dense mass under the splenium of the corpus callosum and a bone defect in the parietal region. Preoperative sagittal $T_{1^{-}}$ weighted (C) and $T_{2}$-weighted (D) magnetic resonance images at the age of 4 months showing a subcutaneous mass due to extracranial extension of the lipoma under the splenium of the corpus callosum with a cord-like connection through the cranium bifidum in the parietal region, and partial defect of both the splenium and rostrum of the corpus callosum.

imaging findings indicated the presence of a mass under the splenium of the corpus callosum that continued to the cranium bifidum of the parietal region with a cord-like connection, and formed a subcutaneous mass (Fig. 2). Since there were no neurological problems, we waited until she was 5 months old to perform partial resection of only the extracranial portion under general anesthesia for cosmetic reasons. The subcutaneous tumor was located inside the skin and the galea. No capsule membrane was macroscopically observed. The histological diagnosis was lipoma (Fig. 3). The patient is now 12 years old, and her course has been uneventful for more than 10 years after the surgery, without epileptic seizures, mental retardation, neurological abnormalities, or remarkable tumor growth (Fig. 4).

\section{Discussion}

Several hypotheses have been proposed for the

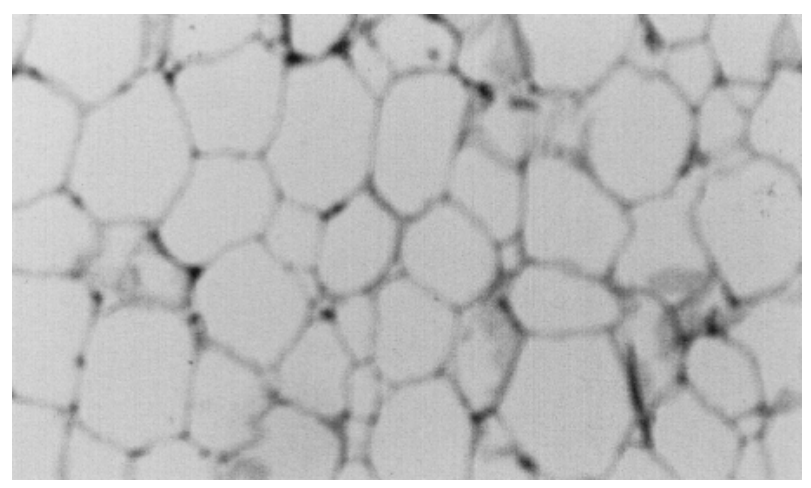

Fig. 3 Photomicrograph of the operative specimen showing adipose tissue with well-differentiated fatty vesicles. HE stain, $\times 100$.
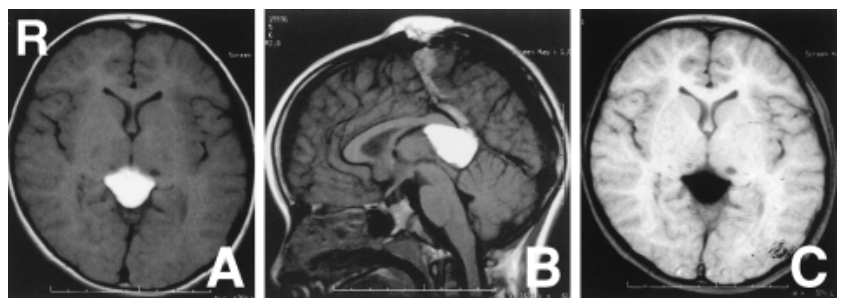

Fig. 4 Axial (A) and sagittal (B) $T_{1}$-weighted magnetic resonance $(M R)$ images at the age of 10 years showing no intracranial increase in the volume of the lipoma. Axial fat-suppression MR image (C) demonstrating the lipoma region as a cold spot.

etiology of intracranial lipomas as follows ${ }^{17,20)}$ : Maldifferentiation of the meninx primitiva; inclusion abnormalities of adipose tissues at the closure margin of the neural groove; hamartomatous maldifferentiation such as proliferation of normal adipose tissues in the pia mater; fatty degeneration of the glia; and a type of dysraphism. In addition, intracranial lipoma has been associated with both spina bifida and cranium bifidum, which are abnormalities of closure of the neural tube. ${ }^{5,20)}$

Extracranial extension of intracranial lipoma via the cranium bifidum has been reported in 11 cases including our present case (Table 1). ${ }^{1,2,8,10-16)}$ Table 1 excludes the cases of lipoma included in encephalocele. Subcutaneous swelling was observed since birth in all cases. Investigation of cases of cranium bifidum associated with lipoma of the corpus callosum suggested that dysraphism was involved in the pathogenesis of this disorder. ${ }^{20}$ Subcutaneous lipoma has also been disconnected from intracranial lipoma as a result of fusion of the skull sutures. ${ }^{3)}$ 
Table 1 Summary of cases of intracranial lipoma with extracranial extension via a bone defect

\begin{tabular}{|c|c|c|c|c|c|c|c|c|}
\hline $\begin{array}{l}\text { Case } \\
\text { No. }\end{array}$ & Author (Year) & Age & Sex & $\begin{array}{l}\text { Main region of } \\
\text { intracranial } \\
\text { lipoma }\end{array}$ & $\begin{array}{l}\text { Region of } \\
\text { bone defect } \\
\text { and swelling }\end{array}$ & $\begin{array}{l}\text { Neurological } \\
\text { symptoms }\end{array}$ & Operation & Outcome \\
\hline \multicolumn{9}{|c|}{ Before CT era: } \\
\hline 1 & $\begin{array}{l}\text { Kinal et al. } \\
(1951)^{11)}\end{array}$ & 17 yrs & M & corpus callosum & $\begin{array}{l}\text { frontal } \\
\text { portion }\end{array}$ & $\begin{array}{l}\text { progressive } \\
\text { seizures, } \\
\text { mental } \\
\text { retardation, } \\
\text { nervousness, } \\
\text { dysphagia, } \\
\text { hemiparesis }\end{array}$ & removal & $\begin{array}{l}\text { death } 10 \text { days } \\
\text { after } \\
\text { operation }\end{array}$ \\
\hline 2 & $\begin{array}{l}\text { Groff et al. } \\
(1951)^{8)}\end{array}$ & $36 \mathrm{yrs}$ & $\mathrm{F}$ & corpus callosum & $\begin{array}{l}\text { frontal } \\
\text { portion }\end{array}$ & $\begin{array}{l}\text { generalized } \\
\text { convulsion } \\
\text { since } 3 \\
\text { years old }\end{array}$ & $\begin{array}{l}\text { for cosmetic } \\
\text { purpose, partial } \\
\text { removal at } 6 \\
\text { months old and } \\
\text { removal of } \\
\text { intracranial } \\
\text { lesion at } 36 \\
\text { years old }\end{array}$ & $\begin{array}{l}\text { death } 6 \text { days } \\
\text { after the } \\
\text { last } \\
\text { operation }\end{array}$ \\
\hline 3 & $\begin{array}{l}\text { Cant and Astley } \\
(1952)^{2)}\end{array}$ & 5 yrs & $\mathrm{M}$ & corpus callosum & $\begin{array}{l}\text { frontal } \\
\text { portion }\end{array}$ & asymptomatic & $\begin{array}{l}\text { for cosmetic } \\
\text { purpose, partial } \\
\text { removal at } 0 \\
\text { years old }\end{array}$ & good \\
\hline 4 & $\underset{(1955)^{15)}}{\text { Nordin et al. }}$ & 15 yrs & $\mathrm{F}$ & corpus callosum & $\begin{array}{l}\text { frontal } \\
\text { portion }\end{array}$ & $\begin{array}{c}\text { convulsion } \\
\text { since } 3 \\
\text { years old }\end{array}$ & $\begin{array}{l}\text { for cosmetic } \\
\text { purpose, partial } \\
\text { removal at } 4 \\
\text { months old and } \\
\text { partial removal } \\
\text { of intracranial } \\
\text { lesion at } 15 \\
\text { years old }\end{array}$ & $\begin{array}{l}\text { death first } \\
12 \text { hours } \\
\text { after the } \\
\text { last } \\
\text { operation }\end{array}$ \\
\hline 5 & $\begin{array}{l}\text { Oftedal } \\
\qquad(1959)^{16)}\end{array}$ & 3 yrs & $\mathrm{F}$ & corpus callosum & $\begin{array}{l}\text { frontal and } \\
\text { parietal } \\
\text { portions }\end{array}$ & $\begin{array}{l}\text { mild mental } \\
\text { retardation } \\
\text { with } \\
\text { hemiparesis, } \\
\text { convulsion } \\
\text { since 2 } \\
\text { years old }\end{array}$ & $\begin{array}{l}\text { for cosmetic } \\
\text { purpose, partial } \\
\text { removal at } 6 \\
\text { months old }\end{array}$ & good \\
\hline 6 & $\begin{array}{l}\text { Addlestostone } \\
\text { and Workman } \\
(1974)^{1)}\end{array}$ & 4 months & $\mathrm{M}$ & corpus callosum & $\begin{array}{l}\text { frontal } \\
\text { portion }\end{array}$ & $\begin{array}{l}\text { mild mental } \\
\text { retardation }\end{array}$ & $\begin{array}{l}\text { total resection at } \\
4 \text { months old }\end{array}$ & good \\
\hline \multicolumn{9}{|c|}{ Since CT era: } \\
\hline 7 & $\begin{array}{l}\text { Kushnet and } \\
\text { Goldman } \\
(1978)^{13)}\end{array}$ & 64 yrs & $\mathrm{F}$ & $\begin{array}{l}\text { corpus callosum } \\
\text { (anterior } \\
\text { part) }\end{array}$ & $\begin{array}{l}\text { frontal } \\
\text { portion }\end{array}$ & $\begin{array}{l}\text { convulsion } \\
\text { since } \\
17 \text { years old }\end{array}$ & no surgery & good \\
\hline 8 & $\begin{array}{l}\text { Kudoh et al. } \\
\qquad(1984)^{12)}\end{array}$ & 3 months & $\mathrm{F}$ & $\begin{array}{l}\text { corpus callosum } \\
\text { (anterior } \\
\text { part) }\end{array}$ & $\begin{array}{l}\text { frontal } \\
\text { portion }\end{array}$ & asymptomatic & $\begin{array}{l}\text { subtotal resection } \\
\text { at } 3 \text { months old }\end{array}$ & good \\
\hline 9 & $\begin{array}{c}\text { Hayashi et al. } \\
{(1986)^{10)}}^{(190)}\end{array}$ & 1 day & $\mathrm{F}$ & $\begin{array}{l}\text { corpus callosum } \\
\text { (anterior } \\
\text { part) }\end{array}$ & $\begin{array}{l}\text { frontal } \\
\text { portion }\end{array}$ & not described & partial removal & good \\
\hline 10 & $\begin{array}{l}\text { Lin et al. } \\
(1995)^{14)}\end{array}$ & 2 months & M & $\begin{array}{l}\text { corpus callosum } \\
\text { (anterior } \\
\text { part) }\end{array}$ & $\begin{array}{l}\text { frontal } \\
\text { portion }\end{array}$ & asymptomatic & $\begin{array}{l}\text { for cosmetic } \\
\text { purpose, partial } \\
\text { removal at } 3 \\
\text { months old }\end{array}$ & good \\
\hline 11 & Present case & 2 months & $\mathrm{F}$ & $\begin{array}{l}\text { splenium of } \\
\text { corpus } \\
\text { callosum }\end{array}$ & $\begin{array}{l}\text { parietal } \\
\text { portion }\end{array}$ & asymptomatic & $\begin{array}{l}\text { for cosmetic } \\
\text { purpose, partial } \\
\text { removal at } 5 \\
\text { months old }\end{array}$ & good \\
\hline
\end{tabular}

In our case, there was a connection between the intracranial lipoma and the extracranial lipoma in association with cranium bifidum, and the involvement of dysraphism was suspected. However, some cases of intracranial lipoma did not develop in the midline region, for example, in the sylvian fissure ${ }^{6,19)}$ and the cerebellopontine angle region, ${ }^{4,19)}$ so we consider that the pathogenesis of lipoma is difficult to clarify and cannot be explained simply by dysraphism. All reported cases of extracranial extension of intracranial lipoma via a bone defect in cranium bifidum were associated with lipoma of the corpus callosum, more specifically in the anterior part of the corpus callosum, from which extracranial extension was recognized via a frontal bone defect (Table 1).

Most patients with lipoma in the corpus callosum are teenagers, followed by patients in their twenties 
at the time of diagnosis. ${ }^{7)}$ When a congenital subcutaneous tumor is recognized, the parents of the patients wish to have the lesion removed. Investigation of the possibility of intracranial lesion should be conducted to identify the intracranial lipoma at an early stage. The subcutaneous tumor was observed at birth in one case, and the intracranial lesion was detected at an early stage by ultrasonography, allowing extirpation of the tumor at the age of 2 months. ${ }^{14)}$ In general, most patients with intracranial lipoma are asymptomatic, but epilepsy occurs in $30-50 \% .{ }^{4,5)}$ Five of the 11 patients with extracranial and intracranial lipoma suffered epilepsy, ${ }^{8,11,13,15,16)}$ which is quite similar to the frequency observed in cases of intracranial lipoma. ${ }^{4,5)}$

The intracranial lipomas commonly show little neoplastic proliferation, but are too difficult to extirpate due to their vascularity and very strong attachment to the surrounding structures. ${ }^{5,7)}$ The lesion must not be forcibly extirpated once the diagnosis of lipoma is established unless there are manifestations of compression by the tumor, such as trigeminal neuralgia ${ }^{21)}$ or facial spasm. ${ }^{4}$ In the present case, the intracranial lipoma did not cause any manifestations of compression, and consequently only the extracranial lesion was resected for cosmetic reasons. Total extirpation of the intracranial lipoma is catastrophic in many cases. ${ }^{18)}$ Accordingly, the intracranial lesion should be treated with the same general measures as for intracranial lipoma, and the extracranial lesion should be treated only if necessary for cosmetic reasons. However, complications may develop such as involvement of the cranial nerves and compression of the brainstem as a result of tumor proliferation during the patient's life. Moreover, one case of asymptomatic lipoma became symptomatic due to hyperplasia of the adipose tissues induced by steroid administration to treat another disorder. ${ }^{9)}$ Therefore, follow up of this tumor is essential.

\section{References}

1) Addlestostone R, Workman JB: Lipoma of the corpus callosum. J Nucl Med 15: 714-716, 1974

2) Cant WHP, Astley R: Lipoma of the corpus callosum. Arch Dis Child 27: 478-479, 1952

3) de Villiers JC, Cluver PF, Peter JC: Lipoma of the corpus callosum associated with frontal and facial anomalies. Acta Neurochir Suppl (Wien) 53: 1-6, 1991

4) Donati F, Vassella F, Kaiser G, Blumberg A: Intracranial lipomas. Neuropediatrics 23: 32-38, 1992

5) Eghwrudjakpor PO, Kurisaka M, Fukuoka M, Mori K: Intracranial lipomas: current perspectives in their diagnosis and treatment. Br J Neurosurg 6: 139-144,
1992

6) Feldman RP, Marcovici A, Lasala PA: Intracranial lipoma of the sylvian fissure: case report and review of the literature. J Neurosurg 94: 515-519, 2001

7) Gerber SS, Plotkin R: Lipoma of the corpus callosum: case report. J Neurosurg 57: 281-285, 1982

8) Groff RA, Liu CT, Leopold RL: Lipoma of the corpus callosum: A survey of the literature, report of two surgical cases. Arch Neurol Psychiatr (Transactions) 65: 253-254, 1951

9) Haga HJ, Thomassen E, Johannesen A, Krakenes J: Neural compressive symptoms appearing during steroid treatment in a patient with intracranial lipoma. Scand J Rheumatol 28: 184-186, 1999

10) Hayashi T, Kadowaki T, Shyojima K, Honda E: Frontoethmoidal lipomeningocele. Childs Nerv Syst 2: 37-39, 1986

11) Kinal ME, Rausmussen G, Hamby WB: Lipoma of the corpus callosum. J Neuropathol Clin Neurol 1: 168-178, 1951

12) Kudoh H, Sakamoto K, Kobayashi N: Lipomas in the corpus callosum and the forehead, associated with a frontal bone defect. Surg Neurol 22: 503-508, 1984

13) Kushnet MW, Goldman RL: Lipoma of the corpus callosum associated with a frontal bone defect. AJR Am J Roentgenol 131: 517-518, 1978

14) Lin KL, Wang HS, Lui TN: Sonographic diagnosis of a corpus callosum lipoma with extracranial extension in an infant. J Ultrasound Med 14: 537-541, 1995

15) Nordin WA, Tesluk H, Jones RK: Lipoma of the corpus callosum. Arch Neurol Psychiatry 74: 300-307, 1955

16) Oftedal SI: Anomalies of the mid-line structures of the brain. Agenesis corporis callosi with a mid-line cyst in one case and a lipoma (?) in another. Acta Psychiatry Neurol Scand 34: 451-463, 1959

17) Sasahira M, Uchimura K, Okada A, Fujimoto $T$, Kawahara Y, Asakura T: [Intracranial lipoma, with special reference to magnetic resonance imaging: a case report]. CT Kenkyu 11: 205-210, 1989 (Jpn, with Eng abstract)

18) Tahmouresie A, Kroll G, Shucart W: Lipoma of the corpus callosum. Surg Neurol 11: 31-34, 1979

19) Truwit CL, Barkovich AJ: Pathogenesis of intracranial lipoma: an MR study in 42 patients. AJR Am J Roentgenol 155: 855-865, 1990

20) Zee CS, McComb JG, Segall HD, Tsai FY, Stanley P: Lipomas of the corpus callosum associated with frontal dysraphism. J Comput Assist Tomogr 5: 201-205, 1981

21) Zimmermann M, Kellermann S, Gerlach R, Seifert V: Cerebellopontine angle lipoma: case report and review of the literature. Acta Neurochir (Wien) 141: 1347-1351, 1999

Address reprint requests to: S. Yamashita, M.D., Department of Neurosurgery, University of Michigan, 5550 Kresge I, Ann Arbor, MI 48109-0532, U.S.A. 